\title{
PLXDC1 Gene
}

National Cancer Institute

\section{Source}

National Cancer Institute. PLXDC1 Gene. NCI Thesaurus. Code C104090.

This gene is involved in capillary formation. 